\title{
Africa's Quest for Long-Term Development: Does NEPAI Provide the Necessary Policy Framework?
}

John Akokpari*

\begin{abstract}
The evasive nature which characterizes Africa's development is something familiar to all. Various ambitious development strategies, implemented since the 1970s, have brought little hope for the reversal of Africa's developmental malaise. The formulation of the New Partnership for Africa's Development (NEPAD) in 2001 and its adoption by the African Union (AU) as the continent's blueprint policy document for development engendered a lot of optimism. This optimism resulted partly from the willingness of African governments to voluntarily undertake what the continent's development partners - the G8 - perceived as 'credible policies' for resuscitating the ailing economies of the continent, and partly from the promise of assistance in the form of accruing $\mathrm{ADE}$ and IDE, debt forgiveness and access to western markets. There is a growing consensus among development experts that the provision of such opportunities would alleviate many of the structural constraints in Africa, consequently catalyzing long-term development. While NEPAD's emphasis on promoting peace, security, democracy, and good governance is commendable, it is however argued that its propensity to gear development solely along neo-liberal lines is problematic in a continent that is grappling with the disappointments of the market-based structural adjustment programmes (SAP).
\end{abstract}

\footnotetext{
* Department of Political Studies, University of Cape Town, Rondebosch 7701, South Africa.E-mail: akokpari@humanities.uct.ac.za
} 
The paper advocates the adoption of viable regional integration schemes that nurture Africa's fragile industries, diversify its predominantly primary production-based economies, promote self-reliance and minimise dependence on external agents. This, it is argued, is a better framework for Africa's longterm development.

\section{Resumé}

Le caractère évasif dont le développement fait l'objet en Afrique est quelque chose de familier. Bon nombre de stratégies de développement ambitieuses mises en ouvre depuis les années 1970 n'ont donné que très peu d'espoir de juguler le malaise développemental dans lequel l'Afrique se trouve. L'élaboration, en 2001, du Nouveau Partenariat pour le Développement de l'Afrique (NEPAD) ainsi que son adoption par l'Union africaine (UA) en tant que schéma directeur continental pour le développement avaient permis d'être optimiste. Cet optimisme était dû, d'une part, à la volonté des gouvernements africains d'adopter délibérément ce que les partenaires au développement du continent - le G8 - considéraient comme étant des 'politiques crédibles' pour ressusciter les économies africaines qui périclitent. D'autre part, cet optimisme découlait de la promesse d'assistance sous la forme d'un ODA et FDI accrus, d'une élimination de la dette, et d'accès aux marchés occidentaux. Les experts en développement s'accordent de plus en plus sur le fait que la création d'opportunités de cette nature pourrait aider à lever bon nombre des contraintes structurelles qui existent en Afrique et, par ricochet, servir de catalyseur pour le développement durable. Même si l'accent que le NEPAD met sur la promotion de la paix, de la sécurité, de la démocratie et de la bonne gouvernance est digne d'éloges, d'aucuns soutiennent que sa tendance à poursuivre les objectifs de développement seulement à l'aide de moyens relevant du néo-libéralisme pose problème dans un continent qui se débat encore avec les désillusions causées par les programmes d'ajustement structurel (PAS) basés sur le marché.

L'article plaide pour l'adoption de plans d'intégration régionale viables qui consolideraient les industries africaines assez précaires, permettraient de diversifier les économies principalement caractérisées par les activités du secteur primaire, favoriseraient l'autosuffisance et minimiseraient la dépendance à des agents extérieurs. D'aucuns croient que c'est la meilleure façon d'assurer un développement durable à l'Afrique

\section{Introduction}

The formulation of the New Partnership for Africa's Development (NEPAD) in 2001 and its subsequent adoption by the African Union (AU) as the continent's blueprint policy document for development have excited hopes and optimism. These hopes are justified against a backdrop 
of failures of previous development strategies to reverse Africa's declining economic fortunes. This paper examines the capacity of NEPAD and the AU to generate long-term development. It argues that while the aims of NEPAD are laudable, its overwhelming thrust to direct Africa's development solely along neo-liberal paths is problematic, given the dismal record of previous neo-liberal development programmes. It opines further that the starting point for long-term development in Africa is the promotion of regional and sub-regional integration that mobilises domestic resources and minimises dependence on the international market. In placing these and related arguments in context, the paper highlights the extent of Africa's developmental crisis, explores the origins of NEPAD, and revisits the debate on NEPAD's ability to establish an auspicious policy framework for African development.

\section{Airica's Crisis and NEPAI's Antecedents}

Africa's decadence and negative indicators are all too familiar to be recounted in detail. In brief, Africa is the only continent in which living conditions have been deteriorating in the last thirty years (Guest 2004, Giddens 1999). Currently between 40 and 60 per cent of its 800 million people live below the poverty line - earning less than the UN threshold of $\$ 1.00$ a day. Africa has high rates of unemployment, illiteracy, mortality and low rates of per capita incomes, real wages and savings. Malnutrition, HIV/AIDS and other diseases, along with inadequate health facilities, have combined to reduce life expectancy in the region. Public access to modern communication infrastructure such as the internet, telephones and satellite television is low compared to other regions (UNDP 2004: 183). Africa's overall economic performance is low, leading to external borrowing, heavier debt burden and reliance on international aid. In the midst of such crushing adversities, overseas development assistance (ODA) and foreign direct investments (FDI) have declined. For example, Africa's share of world trade has plummeted from 2.7 per cent in 1990 to just 2 per cent in 2002 (UNCTAD 2004), underscoring its declining importance and marginalisation in the global economy. The upsurge of neo-liberal globalisation following the demise of communism in the late 1980s has not helped Africa either. On the contrary, competition and liberalisation attending globalisation have presented further developmental challenges to Africa. This, along with the inability of Africa countries to diversity their economies, has heightened the region's vulnerability and uncertainty (Thomson 2000: 168). 
Political conditions in Africa are not better either. Governance is beset with corruption, nepotism and neo-patrimonialism, which together have compounded the continent's development challenges (Chabal 2002). Human right violations and election rigging are rife notwithstanding the widespread adoption of democratic constitutions. Additionally, Africa holds the (in)famous accolade as an epicentre of seemingly intractable intra-state conflicts (Adedeji 1999, Laremont 2002). Worse yet, it has a truncated capacity to manage its environment, increasing its vulnerability to the devastating effects of famine, droughts and floods. Guest (2004: 6) perhaps correctly captures this scenario in noting that 'when the rains fail [Africans] go hungry. And when the rains are too heavy ... they lose their homes'. By every indication, Africa's developmental prospects are seriously circumscribed, raising serious doubts about its ability to meet the UN millennium development goals, including halving poverty by 2015 . Africa, indeed, appears as the 'hopeless continent' (Crewe and Aggleton 2003: 142). It is this condition that NEPAD seeks to reverse. Importantly, NEPAD aims to address Africa's poverty and related structural constraints to place the continent firmly on the path to sustainable development. The formulation of NEPAD could therefore not have come at a better time and high optimism could not have been unexpected.

Yet, NEPAD is not the first development programme Africa has followed in the quest for development. To be sure, NEPAD's antecedents include import substitution industrialisation (ISI), the Lagos Plan of Action (LPA) formulated in 1980 and structural adjustment programmes. None of these, however, made meaningful impact on development. Inspired by the assumptions of the dependency paradigm, attributing the South's underdevelopment to the exploitation of capital and the generally oppressive nature of the international economy, import substitution was adopted by a number of African countries during the 1960s and 1970s to exert state control over development but also to minimise dependency on the external global market. Although subsequently discredited as an explanatory tool, the dependency approach nonetheless gained popularity in the developing world. In Africa, import substitution found expression in the proliferation of public enterprises that dominated nearly all sectors of public life - from agriculture to infrastructure; from banking to marketing and from education to transportation (Nellis 1986: 17-20). While such enterprises temporarily created jobs and theoretically curtailed import bills, they 
were on the whole a failure. Many enterprises were overstaffed, underperformed and inefficient. Consequently, they hardly broke even, let alone made profits and survived on state subsidies. Rather than spurring development, public enterprises entrenched neo-patrimonial politics and became avenues for soliciting elite support (Herbst 1990: 38). The inherent inefficiency in public enterprises and the bankruptcy of ISI as an approach to development became palpable during the economic recession of the 1970s.

The oil crisis of the 1970s and 1980s and the consequent depression in the international economic system spawned a dramatic escalation of Africa's debt. The crisis caused the predictable retreat of private banks (the London Club), which had until then been Africa's main source of credit. The intervention of the international financial institutions (IFIs) and bilateral creditors (the Paris Club), from the 1970s signalled the inexorable demise of ISI as a strategy and statism as an ideology. In return for credit, the IFIs formulated SAPs as the dominant development paradigm. Essentially, SAPs embodied a set of neo-liberal and marketoriented policies, including deregulation, decontrolling, de-subsidisation, devaluations, downsizing and privatisation. In entrenching the market, SAPs also redefined and, in fact, confined the state's role in development to merely 'creating an enabling environment' for the expansion of the private sector depicted as the engine for growth. In retrospect, policy prescriptions and restrictions under SAPs were informed by the World Bank (1981) report, also known as the Berg Report (named after its principal author, Elliot Berg). In contrast to the underlying assumptions of ISI, the Berg Report attributed Africa's crisis to internal causes, including bad governance, over-bloated bureaucracies, state control of exchange rates and marketing as well as its generally overextended nature. Adjustment policies were therefore meant to curb the state's role by transferring its power of distribution to the market thereby undermining its overwhelming control in the economy. The ultimate concern of SAPs was to resuscitate Africa's ailing economies and enhance its debt repayment capacities.

Truncating the traditional role of the state and exciting a mix of anxieties and uncertainties, SAPs faced initial continental resentment, part of which was reflected in the formulation of the Lagos Plan of Action. The LPA was to be an alternative to SAPs whose panoply of obtrusive conditionalities was perceived as intrusive but also inhibitive to longterm development. The LPA aimed to engineer development around 
core regional programmes, dominant among which were collective selfreliance; mobilisation and utilisation of Africa's resources; and regional integration. The state was to be the centrepiece of development in this process (Nyong'o 2002). Together, the LPA's prescriptions were to moderate Africa's precarious dependence on the global market and mitigate its associated largely negative perennial effects. Yet the laudable proposals of the LPA never really saw the light of day. Among other reasons, the LPA lacked implementing structures both at national and regional levels. Moreover, the LPA more or less came to represent a loose set of principles and declarations, which never really wielded power to compel compliance (Shaw 1991, Ikome 2005). Also, weakening the claims of the LPA was the declining fortunes of socialism, which hitherto provided an alternative development path, but which was rapidly losing credence as pro-market reforms were initiated in Russia and Eastern Europe. Importantly, SAPs showed a stronger capacity to attract much needed ODA and FDI than did the LPA. At a time of growing indebtedness and deepening economic crisis, the financial incentives associated with SAPs proved extraordinarily decisive in the contest with the LPA for dominance.

SAPs have since the mid-1990s been interjected, in fact augmented, by new auxiliary programmes designed to facilitate the compliance with the former's conditionalities. One of such policies is the highly indebted poor countries initiative (HIPC). Formulated by the G8 in 1996, the HIPC scheme identified forty-one countries, thirty-three of which are in Africa, as poor and needing debt remission. Debt remission was, however, not unconditional. Prospective beneficiaries were required to have successfully implemented SAPs for at least six years and should have been burdened with a debt whose value was more than 250 per cent and 280 per cent of the country's exports and national revenue respectively. Countries disqualified by the conditions needed to borrow more and sink deeper into debt in order to attain the threshold of eligibility (Akokpari 2001). Although the debt-to-export and revenue ratios were subsequently reduced to 150 and 250 per cent respectively following criticisms and outcry from international NGOs, especially Oxfam and Jubilee 2000, the conditionalities still excluded a good number of African countries. In the end, debt cancellation under the HIPC became more rhetorical than real. Only a few African countries, including Uganda, Ghana and Mozambique, enjoyed partial remission. Five years on, the 
HIPC scheme was eclipsed by the huge euphoria that greeted the formulation of NEPAD.

\section{NEPAD and Airica's Development: The Debate}

NEPAD emerged as an amalgam of three separate development programmes formulated between 2000 and 2001 in South Africa, Senegal and in the Ethiopia-based Economic Commission for Africa - ECA (Ngwane 2002). In South Africa, President Thabo Mbeki developed the Millennium Partnership for African Recovery (MAP), which aimed at addressing Africa's debt and general recovery. MAP enjoyed the support of Presidents Abdelaziz Bouteflika of Algeria and Olusegun Obasanjo of Nigeria. Around the same time, the Senegalese President, Abdoulaye Wade, had formulated the OMEGA Plan, which enjoyed the support of French African countries, was concerned with building regional infrastructure and educational projects. The third was the Global Compact for Africa Recovery (GCAR), initiated by the Economic Commission for Africa (ECA), based in Addis Ababa, Ethiopia, through a mandate from African Ministers of Finance in 2000. The GCAR incorporated the idea of peer review. Sharing fairly common visions on development, the three initiatives were merged in July 2001 at the AU Summit in Lusaka, Zambia, into the New African Initiative (NAI). At the Lusaka summit, a 15-member Heads of State and Government Implementation Committee (HSGIC), representing all the regions of Africa and chaired by Nigeria, was appointed to oversee the implementation of the programme. Three months later, on 23 October 200 I, NAI was renamed NEPAD at a meeting of Heads of States in Abuja.

The objectives of NEPAD were obvious given Africa's egregious development challenges. However, a cursory recap of these aims is essential to place the current analysis in context. Among other things, NEPAD seeks to eradicate poverty as a prelude to sustainable growth and development; encourage employment creation; diversify productive activities to enhance Africa's international competitiveness; increase Africa's access to western markets; and to promote cooperation and integration in Africa (www.nepad.org). In pursuing these objectives, NEPAD identified certain key priority areas, including the maintenance of peace and security through good governance; increased investments in areas like agriculture, communication, tourism, health and education; mobilisation of resources to be achieved through increased resource transfer to Africa via increased ODA, FDI and debt reduction 
(www.nepad.org). These objectives are pursued through the various organs and structures established under NEPAD. The AU is to provide the overall supervisory direction to ensure synergy between its operations and that of NEPAD. Thus, with NEPAD, a new development programme was born, but the critical question is whether it is capable of salvaging Africa from its despondency and set the stage for long-term development. This question has provoked profound polemics that features two diametrically opposed schools of thought - the Afro-optimists and the Afro-pessimists.

\section{The Airo-optimists}

Optimists, composed essentially, but not exclusively of the proponents of NEPAD, see it as opening a new chapter in African development. This view presents NEPAD as the hope for turning back the clock of decay in Africa (Posthumus 2003). Optimism about NEPAD is predicated on a number of implicit and interrelated assumptions. First, NEPAD represents a tacit recognition by Africa of the existence of a developmental crisis and the need to tackle it. By extension, Africa admits that the origins of its crisis are internal and are linked to insecurity, conflicts and bad governance. This thinking stands in sharp contrast to earlier positions depicting Africa's challenges as externally generated. Consequently, Africa seeks, in NEPAD, measures that directly address the internal constraints to development. Proponents of NEPAD argue that the acknowledgement of the severity of a problem and the preparedness to tackle it is itself a step towards an ultimate solution.

Furthermore, optimists hold that as a partnership with developed countries, NEPAD has the ability to attract much needed external aid to Africa. This expectation is nursed against a background of declining ODA and FDI to Africa since the collapse of the Soviet Union and the liberation of Eastern Europe's economies. For example, in 1992, the OECD pledged more than $\$ 45$ billion to the 24 countries in the Eastern European-based Commonwealth of Independent States (CIS). In that year, the OECD's total pledge to Africa with 53 countries was \$34 billion (Kraus 1994: 256; Chege 1996: 6; Katsouris 2000: 6-7). Although total ODA to Africa was $\$ 28$ billion in 1990, this plummeted to $\$ 16.4$ billion in 2000 (Asante 2003: 16). Similarly, FDI to Africa has on the aggregate declined, for example, from $\$ 8.1$ billion in 1996 to $\$ 6.1$ billion in 2000. Although this rose to $\$ 13.8$ billion in 2001, it fell again to $\$ 7$ billion in 2003 (Harsch 2003: 16). In general, whereas ODA and FDI to other regions 
of the world increased, those destined for Africa decreased. NEPAD is expected to fetch Africa $\$ 64$ billion in aid annually if Africa's development partners meet their obligations (The Economist 22 June 2002: 44). Hopes in NEPAD are thus premised on its promise to increase overseas investments and aid to Africa over current levels.

Optimism on NEPAD is, moreover, predicated on the expectation of instigating good governance, whose elusiveness has left damaging implications for Africa. For example, the absence of good governance practices has been identified as one of the fundamental causes of Africa's stagnation (World Bank 1981). For this reason, even overly critical observers of NEPAD commend it for recognising the salience of good governance in development and highlighting its pursuit as a central goal (Landsberg, 2005). NEPAD's key instrument for inspiring good governance is the much heralded African Peer Review Mechanism (APRM). The APRM is a process to which African states submit to periodic review to determine their adherence to principles of good governance set out by the AU during its 2002 July Summit in Durban. The review is done by a seven-member Independent Panel of Eminent Persons (IPEP), which conducts countries through various stages of the review process. The review process, however, is not an end in itself; rather it is an exercise to judge countries but also to assist them to identify policy lapses and create the necessary mechanisms to rectify them. The ultimate goal is to assist governments to improve upon public policies relating to governance. Submission to the review process is voluntary, but failure to sign up leaves negative dents on the governance credentials of countries. Conversely, submitting to the review process serves as a diplomatic baptism into international creditworthiness.

Although the effectiveness of NEPAD in general and the APRM in particular to inspire good governance is questioned (Bond 2003, Taylor 2003, Akokpari 2004), it is claimed to at least bring some moral pressure to bear on countries signing up to it. A favourable governance review report theoretically increases a country's chances of benefiting from the G-8 'enhanced partnership'. This includes gaining access to financial aid and western markets as well as receiving debt remission. By contrast, a damning report jeopardises a country's chances of accessing such crucial development aid. Other incentives for good governance linked, albeit indirectly, to NEPAD are the African Growth and Opportunity Act (AGOA) passed by the US government in 2000. AGOA enables 37 of the 53 African countries to access US markets on meeting liberalisation 
conditionalities. The Millennium Challenge Account (MCA) also established by Washington in 2003 qualifies eight sub-Saharan countries to access part of the $\$ 5$ billion in the account. Qualifications under both AGOA and MCA are dependent on upholding practices of good governance. Thus the passing of the APRM test and the consequent benefits it generates serve as strong incentives for states to aspire to acceptable governance practices.

The AU/NEPAD drive towards minimising political insecurity through evolving new security architecture in Africa is another positive agenda inspiring optimism. The new security architecture is to be driven by subregional organisations and governed by the African solutions to African problems' slogan. The focus on sub-regional formations is informed by a number of interrelated factors, including the retreat of western governments from direct peacekeeping operations, coupled with the inability of the nascent AU to deal with Africa's conflict. The AU/NEPAD security regime seeks to strengthen the capacities of regional organisations in conflict containment, management and resolution through maximising the use of domestic but also external resources. NEPAD has already served to attract external resources from Africa's development partners towards peace and security. For example, having recognised NEPAD as Africa's main development framework, the US has supported every UN resolution on conflict management in the region. Beneath the multilateral level, Washington has worked directly with regional organisations to resolve conflicts. It has, for instance, collaborated with the Kenya-based Intergovernmental Authority on Development (IGAD) to get Sudan's warring factions to negotiate peace. Similarly, it has cooperated with the AU and the UN in resolving the conflict in Darfur. ${ }^{1}$ As well, it has been involved in the establishment of the African Crisis Response Initiative (ACRI) under which close to 9,000 African soldiers were trained for emergency peacekeeping and peace-enforcing duties on the continent. ACRI has since been replaced by the Africa Contingency Operations Training Assistance - ACOTA (Handy 2003).

Britain and France have also developed the African Peacekeeping Training Support Programme (APTSP) and the Renforcement des Capacités Africaines de Maintien de la Paix (RECAMP) respectively. Known collectively as the P-3 Initiatives, these projects are aimed at enhancing Africa's capacity in conflict management thereby reducing its dependence on the West for peacekeeping requirements (Berman and Sams 1998). The EU and the US have assisted the Economic Community 
of West African States (ECOWAS) logistically in the latter's peacekeeping operations in the sub-region. For example the UK assisted ECOWAS's peace operations in Liberia and Sierra Leone, while France provided the first armed response to the Ivorian conflict in the face of fledgling ECOWAS's diplomatic efforts. Africa's western partners have also given assistance to South Africa in its peace initiatives in Burundi and the DRC. In short, NEPAD provides opportunities for cooperation between Africa and western countries in strengthening the fragile security structures on the continent, although it must be noted that these various assistance efforts have been limited to logistics.

Above all, the AU and NEPAD seek to promote regional integration whose importance to Africa's development cannot be overstressed. Previous approaches, including import substitution and structural adjustment, have brought unmitigated disappointments to Africa. Moreover, as Africa stands at the threshold of further marginalisation in a post-Cold War multipolar world dominated by trading blocs (Gilpin 2000: 302), regional integration is widely seen as the answer to its underdevelopment and active participation in the global economy (Adedeji 1976; World Bank 1981). NEPAD's approach is to strengthen regional formations and subsequently create an African common market as envisaged under the 1991 Abuja Treaty. In summarising some of its positives, Koyi (2002: 55) argues that NEPAD provides an avenue for Africa to engage and negotiate with the west for a new place in the international political economy as well as creates opportunities for the region to take ownership of its development process. Together, these factors underscore the efficacy of NEPAD and why the programme raises optimism regarding Africa's long-term development.

\section{The Airo-pessimists}

While NEPAD theoretically promises to set Africa on a development course, it also imparts contradictions and ambiguities, which together raise fundamental questions about its ability to meet its stated objectives. These questions have also become the basis for criticism and pessimism. Although presented as a programme of partnership, the relationship between the west and Africa is criticised for lacking the reciprocity, complementarity or symbiosis that characterise genuine partnerships. On the contrary, it is a fundamentally skewed partnership reminiscent of the relationship 'between a rider and a horse' (Ngwane 2003: 3), or a benevolent and a beggar (Orakwue 2002). Accordingly, the NEPAD 
acronym is either often derided as meaning a 'new partnership for Africa's domination or destruction', or pronounced humorously as 'KNEEPAD' to depict Africa's preparedness to stay longer on its knees while pleading for aid (Orakwue 2002). In fact, Asante (2003: 14) describes the partnership more succinctly as a 'partnership of unequal partners'. These reservations evoke doubts about the genuineness of the partnership between Africa and the G8.

Admittedly, much of these negative comparisons and analogies about NEPAD derive from the unending suspicions about the programme's origins. In contrast to its portrayal as a home-grown project, NEPAD is frequently seen as a construction of the west (Adesina 2003, Bond 2003: 12, Tamele 2003). This critical view argues that a genuinely formulated African programme will eschew the neo-liberal prescriptions embodied in NEPAD, which more or less are the very policies constraining the region's development (Govender 2003). Beset with poverty and adversity, moreover, a truly formulated African development programme would evolve people-centred and poverty-targeted policies, which are visibly missing in NEPAD (Giyose 2003). NEPAD presents a neo-liberal framework, patterned along textbook economics and expected to work from a classical point of view. But worldwide experience shows that textbook economics are not written for economies in decline such as those in Africa, which defy basic neo-classical logic. A neo-liberal programme centred on the market, informed by the logic of trickle-down economics and with a plethora of conditionalities such as NEPAD, can only exacerbate rather than ameliorate poverty and underdevelopment.

If the origins and nature of NEPAD, along with the partnership it evokes with the west, are suspiciously dubious, the commitment of Africa's partners to meet aid obligations is an even bigger source of pessimism. Africa's unmitigated past disappointments with western aid deals substantiate this. In 1986, for example, the UN developed a fouryear recovery programme, the United Nations Programme of Action for African Economic Recovery and Development (UN-PARRED) 19861990. This programme embodied pledges by the international creditor community to provide assistance to Africa. However, the tepid response from the international community condemned UN-PARRED to a premature demise. Again, in 1991, the United Nations New Agenda for the Development of Africa in the 1990s (UN-NADAF) was adopted under which the international creditor community was to commit 0.7 percent of its GNP as ODA to Africa. On their part, African countries 
committed themselves to economic and democratic reforms. However, in return for Africa's wholesale adoption of SAPs and submission to multiparty elections by the close of the decade, only the Netherlands, and the Scandinavian countries of Denmark, Norway and Sweden provided $0.7 \%$ or higher of their GNP as ODA to Africa. In fact, aggregate ODA to Africa actually plummeted from $\$ 28.6$ billion in 1990 to $\$ 16.4$ billion in 2000 (Bentsi-Enchill 1997; Asante 2003: 16). Here, too, donor pledges went unfulfilled.

Similarly, as noted already, the HIPC programme initiated in 1996 brought little debt relief to the region. Africa's latest disappointment came from Gleneagles, Scotland, where the G8 met in July 2005. The AU had expected a massive increment in aid, unconditional debt cancellation and bigger access to western markets given public declarations of the G8, in particular the US and UK, to help Africa out of its quagmires. However, at the conclusion of the meeting, the G8 only adjusted aid figures from the current $\$ 25$ billion a year to $\$ 50$ billion by 2010 . Experts estimate that Africa requires $\$ 100$ billion in development aid and a minimum annual growth rate of seven percent (more than double the current growth rate of between two and three percent) if it is to meet the UN millennium goals (Short 2002). Moreover, of the 18 countries which received some debt cancellation, only 14 were African in contrast to the AU's expectation of total and unconditional remission of the region's debt. As well, little was achieved by way of increasing Africa's access to western markets. Indeed, Africa has a limited ability to compete in western markets where agriculture and other industries are heavily subsidised even if granted unfettered access (Keet 2002). The intermittent trade wars between the EU and the US; Japan and the US; the US and the Caribbean over banana exports; and the ongoing EU disagreements with China over the latter's textiles exports to the former highlight the mercantilist tendencies of western countries. Despite professions to extroversion and market fundamentals, western common markets are innately protectionist (Rugman 2001: 10) and loathe to implement trade policies that are potentially injurious to their industries. Accordingly, there is little evidence to suggest that meeting donor conditionalities under NEPAD will necessarily attract ODA and FDI.

As noted earlier, NEPAD's acclaimed potential to promote good governance, through the innovative APRM, is another source of optimism. However, this optimism is misplaced for at least two reasons: First, as indicated already, submission to the APRM is voluntary. Countries which 
initially signed up can opt out if the process proves intrusive. Second, and more important, the AU lacks the muscle to compel countries to either sign up to the review process or to comply with standards of good governance. This is a major limitation that has left the AU and APRM as a lame leviathan. Four countries - Ghana, Kenya, Mauritius and Rwanda - were reviewed in 2004. However, consistent with the APRM's lack of compulsion, the review process focussed not on whether the stated standards of governance were adhered to, but whether the countries '[were] moving towards these goals' (Africa Research Bulletin, 2004: 15629-30). The incapacity of NEPAD and the AU to generate good governance is also evident in continuous allegations of corruption and nepotism involving top government officials in Africa, and grotesque human right restrictions and abuses in Zimbabwe and Swaziland nearly four years after the adoption of NEPAD and the APRM. Nor have NEPAD and the AU been able to completely stem conflicts and wars in Africa. On the contrary, in spite of successes in ending conflicts in Angola and Mozambique, others have continued to rage. Darfur, Somalia and the Democratic Republic of the Congo (DRC) continue to present challenges to the AU, while peace in the Ivory Coast, Liberia and Sudan remain fragile at best. Other disturbing internal tensions such as in Zimbabwe continue to test the ability of the AU to restore sound governance practices on the continent.

Also, the threat of military intrusion into politics has not completely abated in spite of the AU's declared disdain for unconstitutional changes of governments. Although a military coup was averted in Equatorial Guinea in May 2004, one did occur in Mauritania in August 2005. And while they are commended for championing a new peace and security architecture, the AU and NEPAD impart an ambiguous, often contradictory, stance on some aspects of conflict management. The AU failed to stop the repeated military aggression of Rwanda against the DRC as well as deal with blatant instances of stage-managed elections such as occurred in Togo in May 2005 (Klingebiel 2005: 41) which hold critical implications for stability and security. Election results have continued to be contested, highlighting the fragility of democracy. These lapses and sources of tension are not only an indictment on the AU, but also question the ability of NEPAD to deliver good governance.

The overwhelming neo-liberal orientation of NEPAD is a further source of concern. But this posture is informed not only by the global dominance of neo-liberalism as an ideology, but importantly by the 
assumption tracing Africa's crisis to mainly internal factors. This belief constitutes the core beliefs of the IFI on Africa and explains the persistence of the former in prescribing irresistibly neo-liberal and market-based solutions. Yet, the generally pauperising effects of SAPs, but also the preponderance of economic crisis, deflates optimism about NEPAD. In West Africa, for example, where economic decline and impoverishment have been massive, NEPAD is either unknown, considered an exclusively South African agenda, or a personal Mbeki project. Similarly, OseiHwedie (2003) has noted that having just emerged from war, Angola has become more preoccupied with internal reconstruction and development than with NEPAD. The trajectory of debt and economic decline has rendered countries introverted and largely concerned with finding solutions to internal economic problems. Countries are extroverted only towards potential sources of assistance such as the west. Agyeman-Duah and Daddieh's (1994) contention that Africa's foreign policies, particularly towards western countries, are aimed principally at soliciting external assistance, is as valid today under NEPAD as it was over a decade ago under SAPs. Thus failing to generate tangible relief in a region facing massive socioeconomic adversities, NEPAD is hardly a credible programme for long-term development.

\section{Airica's Hope: Pragmatism Beyond Rhetoric}

In the face of repeated unfulfilled western promises and the inability of previous strategies to induce development, Africa's hopes lie in a development model that minimises dependence on external agencies. I surmise that this model is to be found in regional integration. There are compelling reasons for regionalism in Africa. Among other reasons, Africa is threatened with further marginalisation in the global economy; it has fragmented populations with only five of the 53 countries on the continent having a population of more than 30 million and over a quarter with a population of less than three million. Integration creates bigger markets and stimulates large scale production (Nyong'o 1990: 12). This in turn mitigates Africa's dependence on the world economy, its status as a supplier of raw materials and an importer of manufactured goods (Asante 2007: 29). In addition, regionalism insulates Africa's nascent industries against international competition. For these and related reasons regional integration is an imperative. Integration holds the key to unlocking the door to Africa's development. The AU rightly recognises this necessity and presents regional integration as a cardinal objective of 
NEPAD. However, the AU's call for regional integration has not been accompanied by clear specifications regarding the form of regionalism envisaged for the continent.

The fragility of Africa's economies and its increasing marginality in the international political economy necessitate a regionalist approach that elevates Africa and augments its capacity as an active (as opposed to a marginal) participant in the global economy without aggravating its external dependence. Indeed, Africa requires a special form of integration. It is generally acknowledged that the abatement of the Cold War has ushered in a second wave of regionalism aptly described as the 'new' regionalism. This is contrasted with the first wave or 'old' regionalism, which dominated the integration discourse and practice between the 1950s and 1980s (Lee 2003: 28). Informed by Cold War politics and dominated by the state, the old regionalism was concerned with the economic and political security of states (Hettne 1999; De Melo and Panagriya 1992: 1; Wyatt-Walter 2000: 79-80; Gilpin 2000: 58). The new regionalism, in contrast, pursues objectives that transcend the narrow confines of ideology and security to include a holistic definition of development that includes environmental protection, human security and regional self-sufficiency, among other things. Moreover, in contrast to the old, the new approach to regionalism recognises the critical importance of non-state actors, including informal sectors in the regional integration process.

Yet, in unpacking the new regionalism, at least four competing forms are discernible, including (i) open regionalism, (ii) the WIDER approach, ${ }^{2}$ (iii) regionalism from below, and, (iv) the external guarantors' model. Some of the key assumptions of these are briefly summarised here. Open regionalism is informed by neo-classical assumptions. It presents the market as the key driving force of integration. Consequently, it calls for the dismantling of trade barriers and making states more extroverted. In this regard, open regionalism is consistent with neo-liberal globalisation as it facilitates the incorporation of states into the wider global trading system (Soderbaum 1996: 1-2). By its assumptions, open regionalism with its intrinsic neo-liberal agenda imparts damaging implications for integration in Africa. The imposition of the market-led SAPs in the 1980s was an attempt to make African states more outward looking at the expense of promoting intra-regional trade. Lee (2003: 32) argues that the free trade policies followed in the 1980s under SAPs cost African 
countries much revenue and generated further economic crisis. She argues further that:

during the [1980s] the IMF and World Bank explicitly discouraged market integration because it was seen as being counterproductive to the neo-liberal orthodoxy that enhanced the power of the capitalist core to have unlimited ability to export to the African periphery in the name of efficiency and competition (Lee 2003: 32).

By promoting engagement with the international system, open regionalism has a tendency to perpetuate the skewed and already disconcerting international division of labour under which Africa is encouraged to augment its capacity to produce primary agricultural raw materials and minerals while severely truncating its options towards industrialisation. In conforming to the neo-liberal inclinations, therefore, NEPAD is explicitly opting for open regionalism.

The WIDER approach sees the new regionalism as a multidimensional process that leads to the homogenisation of political, social, cultural and economic policies of states (Soderbaum 1996: 1-2). It proceeds on the premise that globalisation and regionalisation are part of a process of structural change occurring at the global level (Hettne 1999: 2). WIDER sees globalisation as a force escalating "market-driven disorder and turbulence not only on the level of the world but also in local systems' (Hettne et al., 1999: xxxi). As a prescription for this 'disorder' the WIDER approach promotes regionalism from below rather than the state-led approach often initiated from the top. Thus, regionalism is seen as a process by states to increase regional trade and interdependence to serve as a counter-hegemonic force to globalisation (Hettne 1999: 6). In this sense, regionalism offers a path for marginalised regions in Africa, Latin America and in the Arab world to establish large integrated regions that create a new and different global world from the globalisation-generated 'global disorder' of the post-Cold War era (Amin 1999: 54, 62). The prescriptions of the LPA in 1980 calling for collective self-reliance through the mobilisation of regional resources, and curbing reliance on the global market, are consistent with the WIDER approach to integration and development.

Like WIDER, regionalism from below, (also referred to as 'new regionalism') sees regional integration as a counter-force to globalisation. It presents regionalism as a process driven not only by states but also by non-state actors, including informal sectors such as cross border trading activities (Marchand et al., 1999: 900). Globalisation produces winners 
and losers with the latter in the majority. Marginalised in the mainstream of economic activity, losers under globalisation retreated into the informal sector. Regionalism from below acknowledges the phenomenal expansion of the informal sector on account of the failure of the state to meet popular expectations. It therefore calls on developing countries to shun the state-dominated European Union model of integration in favour of non-state approaches to regionalism. Accordingly, regionalism from below incorporates non-state actors and strengthens regional networks in formal and informal trade (Lee 2003: 37). Further it seeks to utilise the opportunities, creativity and innovations of the second economy in the regionalism project. Given the growing size of the informal sector, this version of regionalism is recommended for Africa. With the rapid displacement and replacement of the state by the market under the globalisation-liberalisation regime as the mover of development, and with the former's truncated ability to deliver basic social services, the informal sector is set to become an important agent in Africa's development.

The 'external guarantor's model', (EGM) advocates a partnership between developed and developing countries in establishing regional integration schemes in the latter. It argues that international agencies such the World Bank, IMF, and creditor countries should have greater influence on Africa's regionalism by acting as guarantors to prevent the reversal of politically unpopular microeconomic programmes (Helleiner 1999: 1 18). The EGM is reminiscent of France's role in the French West African Monetary Union, l'Union économique et monétaire ouestafricaine (UEMOA). In this union, the common currency of the UEMOA, the CFA, is linked to the French franc with Paris serving as the guarantor and supervisor. NEPAD seeks to establish a similar supervisory role for Africa's creditors who, in addition to ensuring compliance with conditionalities, also ensure the judicious use of disbursed credit. The immediate implications of this are obvious. The EGM holds mixed blessings for Africa. Whereas it could instigate good governance practices, it could also - as with the experiences with SAPs - potentially entail intrusive and pauperising conditionalities that could worsen Africa's development challenges.

At a critical juncture in its development experience, Africa requires regionalism that combines the best possible opportunities for accelerated development. As Keet (2002: 38) rightly argues, Africa requires 'rounded internally integrated and more soundly-based production economics'. 
To this end, Africa should de-emphasise the open regionalism intrinsic in NEPAD. As noted earlier, open regionalism is extroverted and fosters greater incorporation of states into the capitalist economy, something that has, at least with the experience with SAPs, not helped the course of African development. Moreover, open regionalism creates little opportunities for diversifying the narrow and agricultural-based economies of Africa. Nor is the external guarantor's model of integration good for Africa. With conditionalities, the active involvement of neoliberal institutions and actors would certainly incline Africa towards open regionalism. A more development-friendlier form of regionalism is that which combines elements of the WIDER approach and regionalism from below. These are predominantly introverted approaches to regionalism that mobilise domestic resources, recognise the importance of the huge and expanding informal sector, and above all fit formal and informal structures into the development effort. While recognising the salience and complementary role of external aid, these approaches place emphasis on collective self-reliance. Such approaches to regionalism offer better policy frameworks for long term integration and development. Excessive dependence on the international system as prescribed by open regionalism is inimical to long term development in Africa.

\section{Conclusion}

NEPAD has been hailed by its proponents for giving Africa a lifeline for development. This view is advanced against a background of the failure of past approaches to salvage the continent. Optimism for development is also premised on a set of logical assumptions about NEPAD, including its potential to attract aid and investment; to instigate good governance; to address Africa's perennial conflicts through a new security architecture; and its drive to promote regional integration. However, the paper has demonstrated the limits of these arguments. It noted among other things that NEPAD fails to address poverty, one of Africa's most daunting challenges. Also, its heavy reliance on external agencies truncates its ability to generate development given the west's appalling record of meeting aid obligations to Africa. In addition, there is no certainty about NEPAD's ability to instigate good governance through the APRM. The APRM is a voluntary process devoid of any real mechanisms to compel compliance with good governance practices. These and other inherent limitations of NEPAD rob it of a genuine claim to be a framework for Africa's long term development. 
The importance of regional integration in Africa was emphasised, against a background of its balkanisation, vulnerability to further marginalisation in the world economy, and the need to insulate its nascent industries against international competition. Africa requires a development agenda that captures the objective exigencies of the region. Regionalism provides the framework for evolving such a programme. Yet, while acknowledging the importance of regionalism, Africa requires considerable caution in embracing the new wave of integration. To be sure, the new regionalism embodies various versions some of which can potentially thwart Africa's development. Open regionalism and the external guarantor's models, for example, are not the options for Africa as these imply a stronger incorporation of Africa into the global economy. Whereas a complete de-linkage from the global economy as advocated by the dependency paradigm in the 1970s is preposterous, Africa requires a regionalist approach that seeks to nature fragile industries, diversify its predominantly agricultural economies, promote self-reliance and minimise dependence on external agents. Combined elements of the WIDER approach and regionalism from below can establish this framework.

\section{Notes}

1. The US single-handedly provided financial support in the neighbourhood of $\$ 300$ million towards humanitarian efforts in Darfur and has assisted in airlifting Rwanda and Nigerian monitors to the region.

2. WIDER is the acronym for the World Institute for Development and Economic Research of the UN University in Helsinki, Norway. The Institute undertook studies on integration in the early 1990s to understand the dynamics of the new wave of regionalism after the Cold War. In contrast to classical integration theory the WIDER study sought to examine the role of economic, social, cultural and political issues in the integration process. Out of this seminal study emerged a set of assumptions and prescriptions that came to be referred to as the WIDER approach.

\section{References}

Adedeji, A., 1976, 'The Third World and the Search for an Economic Order', Turkeyen Third World Lectures, Georgetown, Guyana.

Adedeji, A., 1999, 'Comprehending Africa's Conflicts', in Adebayo Adedeji, ed., Comprehending and Mastering African Conflicts: the Search for Sustainable Peace and Good Governance, London: Zed Books, pp. 3-21.

Adesina, J. O., 2002, 'Development and the Challenge of Poverty: NEPAD, PostWashington Consensus and Beyond', Paper presented at the SASA Congress, East London, 30 June-3 July. 
Africa Research Bulletin 41 (2), 2004: 15629-15630.

Agyeman-Duah, B. and Daddieh, K. C., 1994, 'Ghana', in Shaw, T. M. and Okolo, J. E., eds., The Foreign Policies of ECOWAS, London: Macmillan: 32-46.

Akokpari, J., 2001, 'The Debt Crisis, the Global Economy and the Challenges of Development: Sub-Saharan Africa at the Crossroads', Journal of Social Development in Africa, vol. 16 (2): 147-169.

Akokpari, J., 2004, 'The AU, NEPAD and the Promotion of Good Governance in Africa', Nordic Journal of African Studies, 13 (3): 243-263.

Amin, Samir, 1999, 'Regionalisation in response to polarisation', in Bjorn Hettne, Andras Inotai, and Olvando Sunkel, eds., Globalism and the New Regionalism, vol. 1, London: Macmillan: 45-84.

Asante, S. K. B., 1997, Regionalisation and Africa's Development: Expectations, reality and challenges, London: Macmillan.

Asante, S. K. B., 2003, 'NEPAD: A partnership of unequal partners', New African, June: 14-16.

Bentsi-Enchill, N. K., 1997, 'Africa presses for genuine cooperation', Africa Recovery, $11(1): 8-9$.

Berman, E. G. and Sams, K. E., 1998, 'Constructive Disengagement: Western Efforts to Develop African Peacekeeping', ISS Monograph Series No. 33, Pretoria, Institute For Security Studies.

Bond, P., 2003, 'Can NEPAD survive its Proponents, Sponsors, Clients and Peers?', Organisation for Social Research in Eastern and Southern Africa (OSSREA) Newsletter, 21 (3): 12-19.

Chabal, P., 2002, 'The Quest for Good Government and Development in Africa: Is NEPAD the Answer?', International Affairs, 78 (3): 447-462.

Chege, Sam, 1996, 'Donors shift more aid to NGOs', Africa Recovery 13 (1): 6-7.

Crewe, M. and Aggleton, P., 2003, 'Racism, HIV/AIDS and Africa: Some Issues Revisited', South African Journal of International Affairs, 10 (1): 139-149.

De Melo, J. and Panagriya, A., 1992, 'The New Regionalism in Trade Policy', Washington, DC: World Bank and London: Centre for Economic Policy Research.

Giddens, A., 1999, 'Globalisation', Reith Lectures online, http:// news2.thdo.bbc.co.uk/hi/english/static/events/reith_99/week1/week1.htm (12/ $5 / 05)$

Gilpin, R., 2000, The Challenge of Global Capitalism: The World Economy in the 21st Century, Princeton: Princeton University Press.

Giyose, M. P., 2003, 'NEPAD and the Problem of ownership', in Bram Posthumus, ed., NEPAD: A New Partnership?, Amsterdam: Netherlands Institute for Southern Africa: 58-61.

Govender, Venetia, 2003, 'How can/are the SADC NGOs Influencing Regional Developments in terms of NEPAD', in Bram Posthumus, ed., NEPAD: A New Partnership?, Amsterdam: Netherlands Institute for Southern Africa): 25-30.

Guest, Robert, 2004, The Shackled Continent: Africa's past, present and the future, London: Macmillan. 
Handy, Col Russel J., 2003, 'Africa Contingency Operations Training Assistance: Developing Training Partnerships for the Future of Africa', Air and Space Power Journal, Fall: 57-64.

Harsch, E., 2003, 'Foreign investment on Africa's agenda', Africa Recovery, 17 (2): 12-13.

Helleiner, G. K., 1999, 'Linking Africa with the World: a survey of options', in Ademola Oyejide, Benno Ndulu and David Greenway, eds., Regional Integration and Trade Liberalisation in Sub-Saharan Africa, Volume 4: Synthesis and Review, London: Macmillan: 100-133.

Herbst, Jeffery, 1990, 'The Structural Adjustment of Politics in Africa', World Development, 18 (7): 949-958.

Hettne, B., 1999, 'Globalisation and the new Regionalism: The second great transformation’, in Bjorn Hettne, Andras Inotai, and Olvando Sunkel, eds., Globalism and the New Regionalism, Vol. 1, London: Macmillan: 1-24.

Hettne, B., Inotai, A. and Sunkel, O., 1999, eds., Globalism and the New Regionalism, Vol. 1, London: Macmillan: 1-24.

Ikome, Francis, 2005, 'From the Lagos Plan of Action (LPA) to the New Partnership for African Development (NEPAD): The Political Economy of African Regional Initiatives', Unpublished doctoral thesis, School of the Social Sciences, Faculty of Arts, University of the Witwatersrand, Johannesburg.

Katsouris, Christina, 2000, 'New conditions for slow debt relief', Africa Recovery, $14(1): 6-7$.

Keet, Dot, 2002, 'The New Partnership for Africa's Development (NEPAD): and the African Union: unity and integration within Africa, or Integration of Africa into the global economy?', Cape Town: Alternative Information and Development Centre - AIDC.

Klingebiel, Stephan, 2005, 'Africa's New Peace and Security Architecture: Converging the Roles of External Actors and Africa's Interests', African Security Review, 14 (2), 2005: 35-44.

Koyi, Grayson, 2003, 'A View of the Zambian Civil Society on NEPAD', in Bram Posthumus, ed., NEPAD: A New Partnership?, Amsterdam: Netherlands Institute for Southern Africa: 50-57.

Kraus, Jon, 1994, 'The Political Economy of African Foreign Policies: marginality and dependence, realism and choice', in Timothy M. Shaw and Julius E. Okolo, eds., The Foreign Policies of ECOWAS, London: Macmillan: 245-283.

Landsberg, Chris, 2005, 'The Birth and Evolution of NEPAD', Paper presented at the Seminar organised by the Centre for Conflict Resolution (CCR) on 'Building an African Union for the 21 st Century: Relations with the UN, RECs, NEPAD and Civil Society', Vineyard Hotel, Cape Town, South Africa, 20-22 August.

Laremont, R. R., 2002, "The causes of Warfare and the Implications of Peacekeeping in Africa', in Ricardo Rene Laremont, ed., The causes of Warfare and the Implications of Peacekeeping in Africa, Portsmouth: Heinemann: 1-18.

Lee, Margaret, 2003, The Political Economy of Regionalism in Southern Africa, Boulder: Lynne Rienner. 
Marchand, M., Boas, M., and Shaw, T., 1999, 'The Political Economy of New regionalisms', Third World Quarterly, 20 (5): 897-910.

Nellis, John, 1986, 'Public Enterprises in Sub-Saharan Africa', World Bank Discussion Paper, no. 1, Washington, DC: World Bank.

Ngwane, Trevor, 2003, 'Should African Social Movements be part of the "New Partnership for African Development?"', Notes from a Speech to the African Social Forum's African Seminar at the World Social Forum, Porto Alegre, Brazil, 2nd February. KAIROS-Africa <www.web.ca/-iccaf > (accessed: 02/ 08/05).

Nyong'o, P. A., 1990, 'Regional integration in Africa: An unfinished agenda', in Peter Anyang' Nyong'o, ed., Regional integration in Africa: An unfinished agenda, Nairobi: Academy Science Publishers: 3-13.

Nyong'o, P. A., 2002, From the Lagos Plan of Action to NEPAD: The dilemmas of progress in independent Africa, Nairobi: African Academy of Sciences.

Orakwue, Stella, 2002, 'NEPAD or KNEE-PAD', New African, London, May: 3738.

Osei-Hwedie, Kwaku, 2003, 'The Promise of the New Partnership for Africa's Development (NEPAD) The New Hope of Africa?', Paper presented at the Southern African Universities Social Science Conference (SAUSSC), on the theme 'NEPAD and the AU: debts, opportunities and challenges', Pretoria, South Africa, 7-10 December.

Posthumus, Bram, 2003, 'A Conference Report', in Bram Posthumus, ed., NEPAD: A New Partnership?, Amsterdam: Netherlands Institute for Southern Africa: $8-22$.

Rugman, Alan, 2001, The End of Globalisation: Why Global Strategy is a Myth and How to profit from the Realities of Regional Markets, New York: AMACOM.

Shaw, T. M., 1991, 'Reformism, Revisionism and Radicalism in African Political Economy During the 1990s', Journal of Modern African Studies, 29 (2): 191-212.

Short, Clare, 2002, 'We Must Focus on Africa's Development', KAIROS-Africa <www.web.ca/-iccaf > accessed: 02/08/05.

Soderbaum, F., 1996, 'The New Regionalism and the Quest for Development Cooperation and Integration in Southern Africa', Minor Field Study Series. No. 73, Department of Economics, University of Lund, Sweden.

Taylor, Ian, 2003, 'The Failure of the New Economic Partnership for Africa's Development', Contemporary Review, 282 (1648), May: 281-285.

The Economist 22 June 2002: 44.

Thomson, A., 2000, An Introduction to African Politics, London: Routledge.

UNCTAD, 2004, 'Development and Globalization: Facts and Figures', available at http://www.unctad.org/en/docs/gdscsir20041_en.pdf (accessed: 03/08/05).

UNDP, 2004, Human Development Report 2004, New York: Oxford University Press.

World Bank, 1981, Accelerated Development in Sub-Saharan Africa: an agenda for action, Washington DC: World Bank.

www.nepad.org

Wyatt-Walter, A., 2000, 'Regionalism, Globalisation and World Economic Order', in Louise Fawcett and Andrew Hurrell, eds., Regionalism in World Politics: Regional Organisation and International Order, Oxford: Oxford University Press: 74-121. 